\title{
A Novel Nonsense Mutation in Exon 1 and a Transition in Intron 3 of the Lipoprotein Lipase Gene
}

\author{
Toshihiro Nakamura', Tadashi Suehiro', Nobukazu Yasuoka', Michiya Yamamoto', \\ Hiroyuki Ito', Toshinao Yamano², and Kozo Hashimoto'
}

'The Second Department of Internal Medicine, Kochi Medical School, Kochi, Japan.

${ }^{2}$ Tokushima Prefectural Kaifu Hospital, Tokushima, Japan.

\begin{abstract}
We examined the lipoprotein lipase (LPL) gene by single strand conformation polymorphism (SSCP) and by restriction fragment length polymorphism (RFLP) analysis in 106 patients with hypertriglyceridemia to screen for novel mutations and to study the contribution of LPL genetic defects in hypertriglyceridemia. We found a single incidence of a homozygous novel nonsense mutation $\left({ }^{216} \mathrm{G} \rightarrow \mathrm{A} ;{ }^{-14}\right.$ Tryptophan $\rightarrow$ stop codon) in exon 1 and 6 cases heterozygous for a single transition $(C \rightarrow T)$ at six bp upstream from splicing acceptor site of intron 3 . These mutations were not found in 105 normolipidemic controls. The proband homozygous for the nonsense mutation in exon 1, a 74 year old woman, had mild hyperchylomicronemia and her post-heparin plasma showed no LPL protein. However, four heterozygous among family members did not demonstrate hypertriglyceridemia. The frequency of heterozygosity for the $\mathbf{C} \rightarrow \mathbf{T}$ transition in intron 3 was significantly different from that in normolipidemic controls. Therefore, it was suggested that the mutation is involved in hypertriglyceridemia. All of the heterozygotes were men with 4 patients having impaired glucose tolerance or diabetes mellitus. These observations suggest that this polymorphism in intron 3 combined with other as yet undefined factors may be related to hypertriglyceridemia. J Atheroscler Thromb, 1996 ; 3 : 17-24.
\end{abstract}

Key words : Lipoprotein lipase, Hypertriglyceridemia, Nonsense mutation, Polymorphism

Lipoprotein lipase (LPL) is a 55 kilo-dalton glycoprotein which hydrolyzes the triglyceride component of circulating chylomicrons and very low density lipoproteins to free fatty acids (1-4). The human LPL gene is assigned to chromosome 8p22 (5) and has a length of $30 \mathrm{~kb}$ comprising 10 exons $(6,7)$. The first nine exons encode a 475-amino acid protein including a 27 -amino acid signal peptide (8), while exon 10 encodes the untranslated 3 ' end of the mRNA. Homozygosity and compound heterozygosity for LPL gene deficiencies cause hyperchylomicronemia, a relatively rare disorder occurring at a frequency of about one in a million, which is often accompanied by pancreatitis and eruptive xanthomas (9). In the last few years, over 30 different mutations which result in defective LPL have been identified.

Address for correspondence: Toshihiro Nakamura, The Second Department of Internal Medicine, Kochi Medical School, Kohasu, Okoh-cho, Nankoku, Kochi 783, Japan.

Received July 5, 1995.

Accepted for publication December 14, 1995.
It has been reported that some heterozygous individuals with a familial LPL defect have hypertriglyceridemia (10-12). Therefore, heterozygosity for LPL defects may be involved in hyperlipoproteinemia such as type Ilb, IV or V. We examined the LPL gene in patients with hypertriglyceridemia to screen for novel mutations and to study whether an abnormal LPL gene is involved in hypertriglyceridemia. Heterozygotes with normal LPL activity or mass in postheparin plasma have been reported (10-12), so we directly studied the LPL gene in patients with hypertriglyceridemia without measuring LPL activity or mass. Most dysfunctional LPL genetic defects reported to date are the result of one point mutation (13). Therefore, we used single-stranded conformation polymorphism (SSCP) analysis, an efficient method for detecting single base differences in polymerase chain reaction $(\mathrm{PCR})$ products $(14,15)$, to search for mutations.

Consequently, we found a novel nonsense mutation in exon 1 and a novel single transition in intron 3 . We then 
further studied the frequencies of the mutant LPL alleles and clinical backgrounds of the patients with mutant alleles.

\section{Materials and Methods}

\section{Materials}

The LPL gene was examined by SSCP analysis in 70 patients whose plasma triglyceride levels were over $300 \mathrm{mg} /$ $\mathrm{dl}$, regardless of medication of lipid-lowering drugs. At the next stage, 106 hypertriglyceridemic patients including the above patients were examined by PCR-restriction fragment length polymorphism (RFLP) analysis to detect the novel mutant LPL alleles which were found in this study. Among the 106 patients examined (72 men and 34 women, mean \pm standard deviation of age were $48 \pm 9$ and $49 \pm 17$ years, respectively), there were 38 patients with impaired glucose tolerance or diabetes mellitus, 47 patients with a habit of drinking alcohol, and 21 patients with mild liver disorder. The underlying diseases in all patients were stable. The means \pm standard deviation of plasma triglyceride level, total cholesterol level and HDL-cholesterol level in 106 patients were $724 \pm 790(273-5,230), 243 \pm 102(102-856)$ and $51 \pm 21$ (16-126) $\mathrm{mg} / \mathrm{dl}$, respectively.

For the novel mutations found in this study, 105 normal healthy controls $(59$ men and 46 women: mean age were $50 \pm 12$ and $48 \pm 11$ years) with normolipidemia (triglyceride $<150 \mathrm{mg} / \mathrm{dl}$, total cholesterol $<220 \mathrm{mg} / \mathrm{dl}$ ) were also investigated by RFLP analysis. They demonstrated neither glucose intolerance, liver disorder, nor renal disorder, and had mean plasma triglyceride level and total cholesterol level of $86 \pm 27$ and $180 \pm 26 \mathrm{mg} / \mathrm{dl}$, respectively.

\section{DNA extraction and PCR}

Genomic DNA was extracted from whole blood using a commercial kit (GENOMIX ${ }^{\circledR}$; Paroma, LA, USA). Each exon, 1 to 9 including the exon-intron boundary of the LPL gene was amplified by PCR, as follows. Samples were denatured at $96^{\circ} \mathrm{C}$ for $5 \mathrm{~min}$, and amplification was carried out in an automated thermocycler (Programtempcontrol System PC-700 ${ }^{\circledR}$; Astec, Fukuoka, Japan) for 30 cycles. Each cycle consisted of denaturation at $95^{\circ} \mathrm{C}$ for $45 \mathrm{sec}$, annealing at $56^{\circ} \mathrm{C}$ (exon 1, 4, 5 and 6 ), $51^{\circ} \mathrm{C}$ (exon 2, 3, 7, and 9) or $48^{\circ} \mathrm{C}$ (exon 8) for $45 \mathrm{sec}$ and extension at $70^{\circ} \mathrm{C}$ for 90 $\mathrm{sec}$. The oligonucleotide primers described previously (for exons 2, 6, 7, and 9, and the antisense primer of exon 8) were used for PCR (16) and other primers were established in this study as shown in Table 1.

\section{PCR-SSCP}

Nonisotopic SSCP analysis was performed as described by Yap and McGee (15). Aliquots of each PCR product (10 $\mu$ l) were denatured by adding $1 \mu \mathrm{l}$ of mixture of $0.5 \mathrm{M} \mathrm{NaOH}$ and $10 \mathrm{mM}$ EDTA, heating at $42^{\circ} \mathrm{C}$ for $5 \mathrm{~min}$ then, cooling on ice and resolving with $2 \mu \mathrm{l}$ of $100 \%$ formamide. The samples were electrophoresed on $6 \%$ nondenaturing polyacrylamide gels $(200 \times 200 \times 0.75 \mathrm{~mm})$ in TBE buffer $(50 \mathrm{mM}$ Tris, $48 \mathrm{mM}$ borate and $1 \mathrm{mM}$ EDTA) with or without glycerol, at $4{ }^{\circ} \mathrm{C}$ or at room temperature for appropriate periods $(70-120 \mathrm{~min})$. The gels were stained with ethidium bromide. Due to the size of exon 6, its PCR product was digested by Hae III (Takara Shuzo, Kyoto, Japan) and the digested fragments (123 bp and $210 \mathrm{bp}$ ) were electrophoresed.

\section{DNA sequence}

PCR products showing an abnormal pattern were purified by separation on an agarose gel (Ultra Pure Agarose; Life Technologies, Gaithersburg, MD, USA), cutting out the band and extracting the DNA fragment using a commercial kit (GENE CLEAN2 ; Bio 101, Lajolla, CA, USA). The purified DNA fragment was directly sequenced using a CircumVent ${ }^{\mathrm{TM}}$ Thermal Cycle Dideoxy DNA Sequencing Kit (New England Biolabs, Beverly, MA, USA).

The $690 \mathrm{bp} 5^{\prime}$ flanking region from the ATG initiation codon of the LPL gene was amplified by PCR with primers PF5 and PF3 as shown in Table1, and its sequence was determined by the same method as described above.

\section{PCR-RFLP}

The novel nonsense mutation in exon 1 was confirmed by restriction enzyme digestion of amplified genomic DNA to enable examination of large populations. Since there are no suitable restriction endonuclease sites which overlap the mutation, we amplified the exon 1 fragment using an antisense primer, 5'-CCCTCCGCGGGAGGCGGTCAGAGACTGGAG-3', with a mismatch of two base pairs (underline), which introduced a new cleavage site for PshAl (Takara Shuzo, Kyoto, Japan) in the mutant alleles but not in normal alleles (Fig. 1A). The sense primer and the PCR conditions were the same as described above for the amplification of exon 1. Aliquats of the PCR product $(10 \mu \mathrm{l})$ were digested with 10 units of PshAl overnight, and separated on a mixed agarose gel consisting of $1 \%$ agarose and 3\% NuSieve (FMC BioProducts, Rockland, ME, USA), followed by staining with ethidium bromide.

The novel mutation in intron 3 was also confirmed by restriction enzyme digestion of amplified genomic DNA (Fig. 2A). The PCR product of exon $4(10 \mu \mathrm{l})$ was digested with 10 units of Mboll (Takara Shuzo, Kyoto, Japan) over night, separated on an agarose gel and stained as described above.

A single transversion of ${ }^{1595} \mathrm{C} \rightarrow \mathrm{G}$ in exon 9 was detected by Hinf-I restriction digestion as described previously (17).

\section{RT-PCR}

Blood samples were taken into tubes containing heparin from a patient with the $\mathrm{C} \rightarrow \mathrm{T}$ change in intron 3 and from a control subject. Mononuclear cells were separated by the Ficoll-Paque gradient method (Pharmacia Biotech AB, Uppsala, Sweden) and were suspended with RPMI-1640 (Life Technologies, Grand Islandn NY, USA) and plated on tissue culture dishes, followed by incubation in $\mathrm{CO}_{2}$ incubator at $37^{\circ} \mathrm{C}$ for a week. Monocyte-derived macrophages adhering 


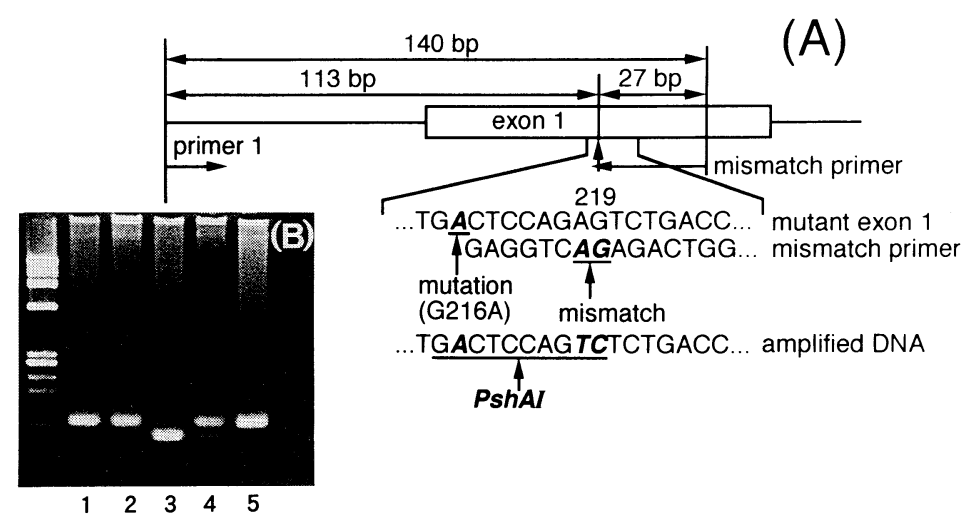

Fig. 1. (A) Schematic illustration of exon 1 of the $L P L$ gene and primers for PCR amplification which was digested with PshAl for detection of the nonsense mutation $\left({ }^{216} \mathrm{G} \rightarrow \mathrm{A}\right)$. The antisense primer contained a two bp mismatch.

(B) Agarose gel electrophoresis of exon 1 PCR product after digestion with PshAl. Lanes 1, 2, 5 : PCR products from normal subjects; Lane 3: from a homozygote (proband) ; Lane 4: from a heterozygote (daughter).

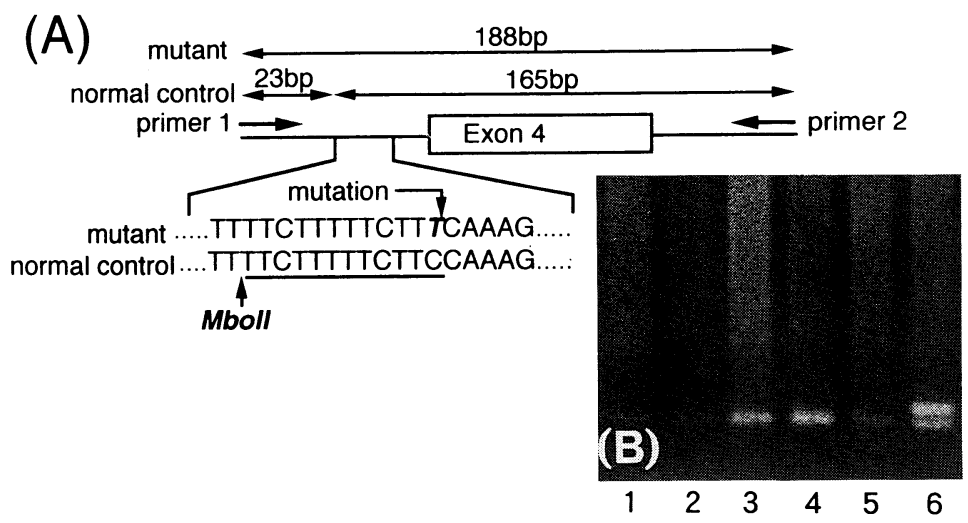

Fig. 2. (A) Schematic illustration of the intron 3-exon 4 boundary of the LPL gene and primers used for PCR amplification which was digested with Mboll.

(B) Agarose gel electrophoresis of exon 4 PCR product after digestion with Mboll. Lanes 1-5: PCR products from normal subjects; Lane 6 : from a heterozygote.

to dishes were harvested for as a source of mRNA. Total RNA was isolated using TRIzol ${ }^{\mathrm{TM}}$ solution (Life Technologies, Gaithersburg, MD, USA) and $0.5 \mu \mathrm{g}$ aliquots of RNA were reverse transcribed using RNA buffer $(10 \mathrm{mM}$ Tris- $\mathrm{HCl}, 50$ $\mathrm{mM} \mathrm{KCl}, \mathrm{pH} 8)$, dNTPs mixture (1 mM), RNase inhibitor (1 Uint/ $\mu l)$, DTT $(2 \%)$, reverse transcriptase $(0.25 \mathrm{Unit} / \mu \mathrm{l})$, and $3^{\prime}$ primer (Table 1, RT2). Then, PCR was performed with Taq DNA polymerase and $5^{\prime}$ primer (Table 1, RT1), and the PCR product between exon 2 and exon 5 was obtained. This sample was developed on a $2 \%$ agarose gel.

\section{LPL mass}

The LPL mass of post-heparin plasma was determined in some patients with LPL gene abnormality. After fasting for over 12 hours, plasma samples were obtained $10 \mathrm{~min}$ after the injection of heparin (Novo Industry, A/S, Denmark) at a dose of $30 \mathrm{lU} / \mathrm{kg}$ body weight. LPL mass was measured using an
ELISA kit (MARKIT ${ }^{\circledR}$-FLPL; Dainippon Pharmaceutical CO., Osaka, Japan) (18).

\section{Results}

SSCP

The PCR product of exon 1 from one patient and PCR products of exon 4 from 5 patients showed abnormal patterns on SSCP gels (Figs. 3 and 4). The PCR products of exon 9 from 3 patients also revealed abnormal patterns (not shown).

\section{Direct sequence}

Sequence analysis of exon 1 from the patient with abnormal SSCP revealed a single base substitution of ${ }^{216} \mathrm{G} \rightarrow A$ resulting in the substitution of a stop codon (TGA) for ${ }^{-14} \mathrm{Trp}$ (TGG) (Fig. 5). The sequence indicated that the patient was 
Table 1. Sequences of primers for PCR of exon 1-9 including exon-intron boundaries, $5^{\prime}$ flanking region, and for RT-PCR of the LPL gene.

\begin{tabular}{|c|c|c|c|}
\hline \multicolumn{4}{|c|}{ Primers for PCR of exon 1-9 } \\
\hline \multirow[t]{2}{*}{ exon 1: } & sense & (P15) & ; 5'-GCTCATCAGTCGGTCCGCGC-3' \\
\hline & antisense & (P13) & ; 5'-GGTCTGCAGGTGGAGGGTAG-3' \\
\hline \multirow[t]{2}{*}{ exon 2: } & sense $^{\#}$ & (P25) & ; 5'-CTCATATCCAATTTTTCCTT-3' \\
\hline & antisense ${ }^{\#}$ & (p23) & ; 5'-CTCTTCCCCAAAGAGCCTCC-3' \\
\hline \multirow[t]{2}{*}{ exon 3: } & sense & (P35) & ; 5'-GAAAGCTTGTGTCATCATCT-3' \\
\hline & antisense & (P33) & ; 5'-TGGACACATAAGTCTCCTTC-3' \\
\hline \multirow[t]{2}{*}{ exon 4: } & sense & (P45) & ; 5'-GCAGAACTGTAAGCACTTC-3' \\
\hline & antisense & (P43) & ; 5'-CСТCTTATGATAAGACCAAC-3' \\
\hline \multirow[t]{2}{*}{ exon 5: } & sense & (P55) & ; 5'-ACAAATCTGTGTTCCTGCTT-3' \\
\hline & antisense & (P53) & ; 5'-AGTCACATTTAATTCGCTTC-3' \\
\hline \multirow[t]{2}{*}{ exon 6: } & sense $^{\#}$ & (P65) & ; 5'-GCCGAGATACAATCTTGGTG-3' \\
\hline & antiseese ${ }^{\#}$ & (P63) & ; 5'-GCATGATGAAATAGGACTCC-3' \\
\hline \multirow[t]{2}{*}{ exon 7 : } & sense $^{\#}$ & (P75) & ; 5'-CATGTTCGAATTTCCTCCCC-3' \\
\hline & antisense ${ }^{\#}$ & (P73) & ; 5'-ATGACCGCCCCCCTGTGCTA-3' \\
\hline \multirow[t]{2}{*}{ exon 8: } & sense & (P85) & ; 5'-ATAACTAACCAAATTTATTG-3' \\
\hline & antisense ${ }^{\#}$ & (P83) & ; 5'-AAGGAAGAAAAATACATTTA-3' \\
\hline \multirow[t]{2}{*}{ exon 9: } & sense $\#$ & (P95) & ; 5'-ТАТТСАСАТССАТТТТТТТ--3' \\
\hline & antisense ${ }^{\#}$ & (P93) & ; 5'-GTCAGCTTTAGCCCAGAATG-3' \\
\hline \multicolumn{4}{|c|}{ Primers for $5^{\prime}$ flanking region } \\
\hline & sense & (PF5) & ; 5'-CACCAGATTGTACAAGCACA-3' \\
\hline & antisense & (PF3) & ; 5'-GGCTाTGCTCTCCATCTCGG-3' \\
\hline \multicolumn{4}{|c|}{ Primers for RT-PCR (exon 2-exon 5) } \\
\hline & sense & (RT1) & ; 5'-ACCAGACTCCAATGTCATTG-3' \\
\hline & antisense & (RT2) & ; 5'-TCTGGTGAATGTGTGTAAGA-3' \\
\hline
\end{tabular}

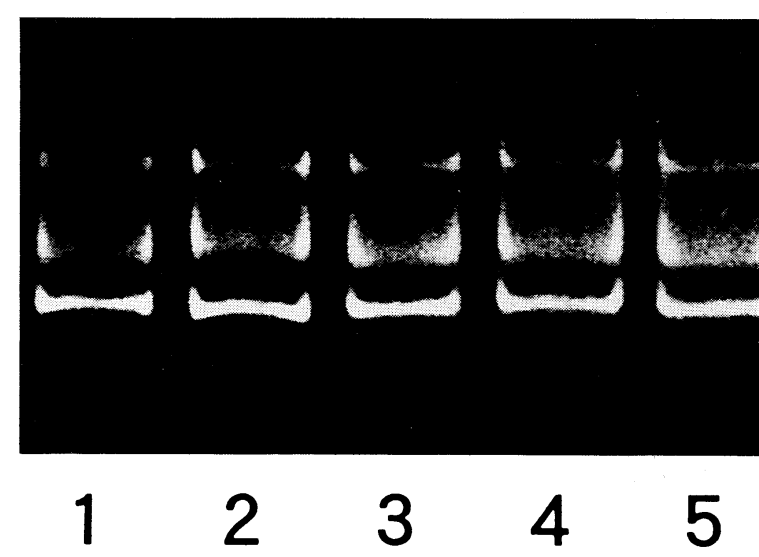

Fig. 3. SSCP analysis of exon 1 of the LPL gene. Lanes 1, 3, 4 and 5 : PCR products from normal subjects; Lane 2: from a homozygote.

homozygous for this mutant allele. There were no differences from the published DNA sequence $(8,19)$ or from the sequence of normal controls in the remaining exons 2-9.

A single base substitution of $\mathrm{C} \rightarrow \mathrm{T}$ at $6 \mathrm{bp}$ upstream from the splice acceptor site was also detected by sequence analysis of exon 4 PCR product from five patients with abnormal SSCP (Fig. 6). All of these were heterozygotes and showed no differences from the published sequence in

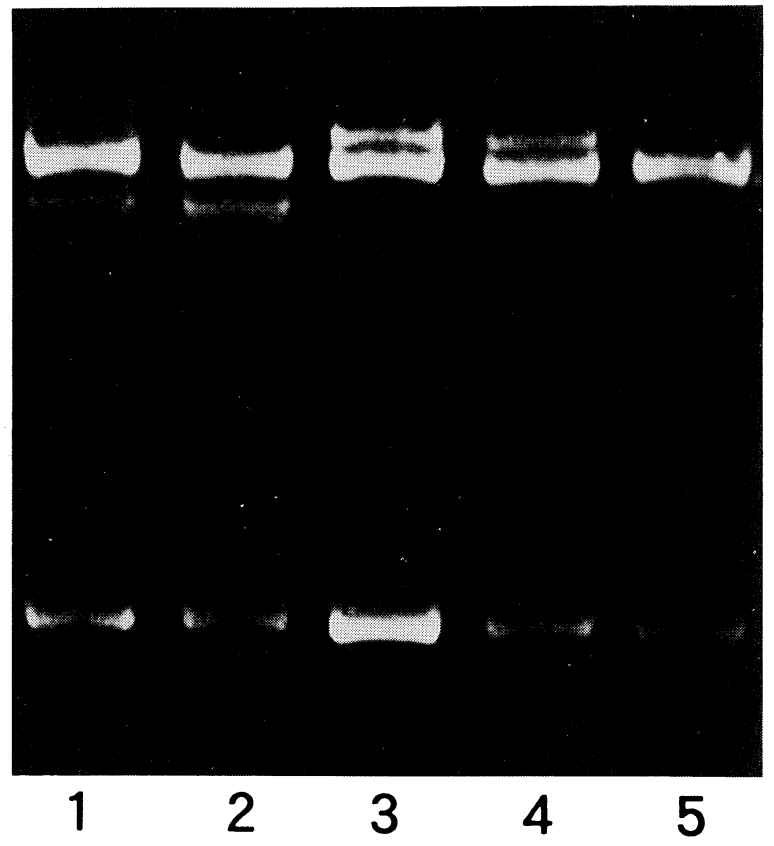

Fig. 4. SSCP analysis of exon 4 including the exonintron boundary of the LPL gene. Lanes 1, 2 and 5 : PCR products from normal subjects; Lanes 3 and 4 : PCR products from heterozygous individuals. 


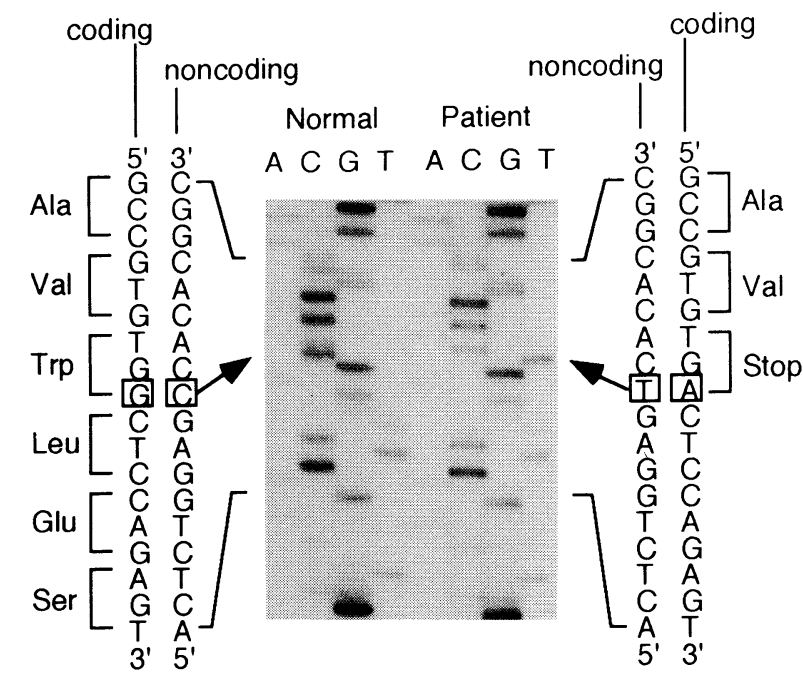

Fig. 5. Sequences of the normal and mutant exon 1. DNA sequence of the coding strand from the mutant showed the ${ }^{216} \mathrm{G} \rightarrow \mathrm{A}$ substitution, resulting in substitution of a stop codon for Tryptophan.

all exons and the 690 bp $5^{\prime}$ flanking region from ATG initiation codon $(8,19,20)$.

\section{RFLP of ${ }^{216} \mathbf{G} \rightarrow A$ in exon 1}

The PCR products of exon 1 from normal controls after PshAl digestion yielded one $140 \mathrm{bp}$ band. On the other hand, the product from the patient with abnormal SSCP pattern yielded one band of $113 \mathrm{bp}$ and another fragment of 27 bp which was not clearly detected on the gel (Fig. 1B). The PCR product of her heterozygous daughter, yielded two bands of $140 \mathrm{bp}$ and $113 \mathrm{bp}$.

The homozygous proband, was a 74-year-old woman who was hospitalized for syncope. She was not suffering from pancreatitis or ischemic heart disease. Her maximum plasma triglyceride level was $1,639 \mathrm{mg} / \mathrm{dl}$ and her ordinary triglyceride levels were approximately $800 \mathrm{mg} / \mathrm{dl}$. Lipoprotein electrophoretogram showed increased chylomicrons. LPL protein was not detected in her post-heparin plasma. The LPL gene of her husband was normal. Four of the proband's five children were examined. They were hetero-

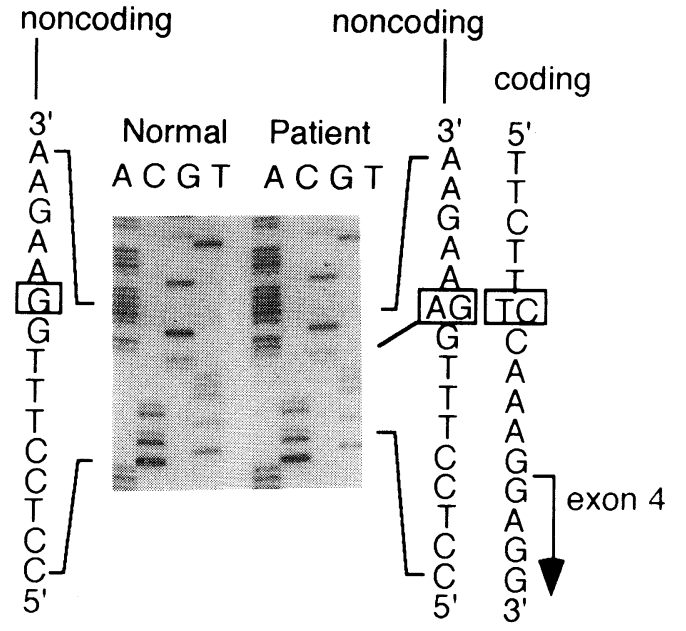

Fig. 6. Sequences of the the normal and mutant intron 3-exon 4 boundary. DNA sequence of the coding strand from the mutant showed the $\mathrm{C} \rightarrow \mathrm{T}$ substitution at $6 \mathrm{bp}$ upstream from the splicing acceptor site in intron 3.

zygous for the mutation and their plasma triglyceride levels were entirely normal. Among 3 children in whom LPL mass was examined in post-heparin plasma, two had normal LPL mass, while one demonstrated the lower limit (Table 2). The children manifested no obesity, diabetes mellitus nor habitual alcohol drinking behavior. They mainly ate vegetables and fish.

RFLP analysis revealed no case with this nonsense mutant among the other hypertriglyceridemic patients or 105 normolipidemic control subjects.

\section{RLFP of $\mathbf{C} \rightarrow \mathbf{T}$ in intron $\mathbf{3}$}

The PCR product of exon 4 from normal controls after Mboll digestion yielded two bands of $165 \mathrm{bp}$ and $23 \mathrm{bp}$, although the $23 \mathrm{bp}$ band could not be detected on the gel. On the other hand, the PCR product from the patients with a $\mathrm{C} \rightarrow \mathrm{T}$ change in intron 3 yielded only one band of $188 \mathrm{bp}$ after digestion. The PCR products showing abnormal SSCP patterns revealed two bands of $165 \mathrm{bp}$ and $188 \mathrm{bp}$ on gels, that is, they were heterozygous for the mutation (Fig. 2B).

RFLP analysis by Mboll digestion in 106 hypertriglycer-

Table 2. Clinical data of family members with the nonsense mutation $\left.{ }^{216} \mathrm{G} \rightarrow A\right)$ in exon 1 .

\begin{tabular}{|c|c|c|c|c|c|c|c|c|c|}
\hline Case & Sex & $\begin{array}{l}\text { Age } \\
y r\end{array}$ & Mutation & $\begin{array}{c}\mathrm{BMI} \\
\mathrm{kg} / \mathrm{m}^{2}\end{array}$ & $\begin{array}{c}\mathrm{TG} \\
\mathrm{mg} / \mathrm{dl}\end{array}$ & $\begin{array}{c}\mathrm{TC} \\
\mathrm{mg} / \mathrm{dl}\end{array}$ & $\begin{array}{l}\mathrm{HDL} \\
\mathrm{mg} / \mathrm{dl}\end{array}$ & $\begin{array}{c}\mathrm{LPL}^{\#} \\
\mathrm{mg} / \mathrm{ml}\end{array}$ & Complication \\
\hline Proband & $\mathrm{F}$ & 76 & Homo & 25.7 & 1,639 & 232 & nd & $<20$ & NIDDM \\
\hline Daughter-1 & $\mathrm{F}$ & 55 & Hetero & 20.7 & 73 & 199 & 52 & 209 & none \\
\hline Son & $\mathrm{M}$ & 52 & Hetero & 22.0 & 110 & 134 & 45 & 123 & none \\
\hline Daughter-2 & $\mathrm{F}$ & 50 & Hetero & 22.5 & 59 & 154 & 55 & 251 & none \\
\hline Daughter-3 & $\mathrm{F}$ & 48 & Hetero & 19.5 & 46 & 125 & 36 & nd & none \\
\hline Husband & $M$ & 86 & None & 19.8 & 80 & 186 & 37 & nd & none \\
\hline
\end{tabular}

\# : LPL mass in post-heparin plasma (heparin 30 unit $/ \mathrm{kg}$ body weight). nd: no data (failure of examination in the proband because of turbid plasma), Normal LPL mass : $223 \pm 66 \mathrm{ng} / \mathrm{ml}(18)$. 
Table 3. Clinical data of the patients with the $\mathrm{C} \rightarrow \mathrm{T}$ transition in intron 3 .

\begin{tabular}{|c|c|c|c|c|c|c|c|c|c|c|c|}
\hline No & Case & Sex & $\begin{array}{c}\text { Age } \\
\mathrm{yr}\end{array}$ & $\begin{array}{c}\mathrm{BMl} \\
\mathrm{kg} / \mathrm{m}^{2}\end{array}$ & $\begin{array}{c}\mathrm{TG} \\
\mathrm{mg} / \mathrm{dl}\end{array}$ & $\begin{array}{c}\mathrm{TC} \\
\mathrm{mg} / \mathrm{dl}\end{array}$ & $\begin{array}{l}\mathrm{HDL} \\
\mathrm{mg} / \mathrm{dl}\end{array}$ & $\begin{array}{l}\mathrm{ApoCll} \\
\mathrm{mg} / \mathrm{dl}\end{array}$ & $\begin{array}{l}\mathrm{LPL}^{\#} \\
\mathrm{ng} / \mathrm{ml}\end{array}$ & Complication & Alcohol \\
\hline 1 & $\mathrm{YT}$ & $M$ & 41 & 33.0 & 751 & 346 & 102 & 9.2 & 289 & IGT & - \\
\hline 2 & KK & $M$ & 60 & 21.3 & 476 & 102 & 21 & nd & 244 & NIDDM & + \\
\hline 3 & $Y Y$ & $M$ & 59 & 25.0 & 424 & 203 & 29 & 5.6 & 128 & none & + \\
\hline 4 & $\mathrm{HM}$ & $M$ & 49 & 23.2 & 1183 & 243 & 64 & 16.4 & nd & NIDDM & + \\
\hline 5 & YO & $M$ & 46 & 27.7 & 386 & 199 & 58 & nd & nd & NIDDM & + \\
\hline 6 & $\mathrm{MM}^{\mathbb{S}}$ & $M$ & 39 & nd & 273 & 265 & nd & nd & nd & nd & nd \\
\hline
\end{tabular}

nd : no data, ${ }^{*}$ : LPL mass in post-heparin plasma (heparin $30 \mathrm{lU} / \mathrm{kg}$ body weight), ${ }^{\$}$ : The patient (MM) could not be followed up, ApoCll level of normal control : $1.2-4.9 \mathrm{mg} / \mathrm{dl}$, Normal LPL mass : $223 \pm 66 \mathrm{ng} / \mathrm{ml}$ (18).

idemic patients revealed another heterozygote whose DNA sequence of intron 3 showed the same change of $\mathrm{C} \rightarrow \mathrm{T}$. However, there were no changes in the LPL gene from 105 normolipidemic control subjects. There were significant differences in the frequencies of this mutation between the hypertriglyceridemic and the normolipidemic control group (Fisher's exact probability test; $P=0.015$ ). Table 3 shows the plasma lipid levels and clinical backgrounds of 6 patients with the $\mathrm{C} \rightarrow \mathrm{T}$ change in intron 3. All of these patient were male. No follow up was performed for one patient $(\mathrm{MM})$ and

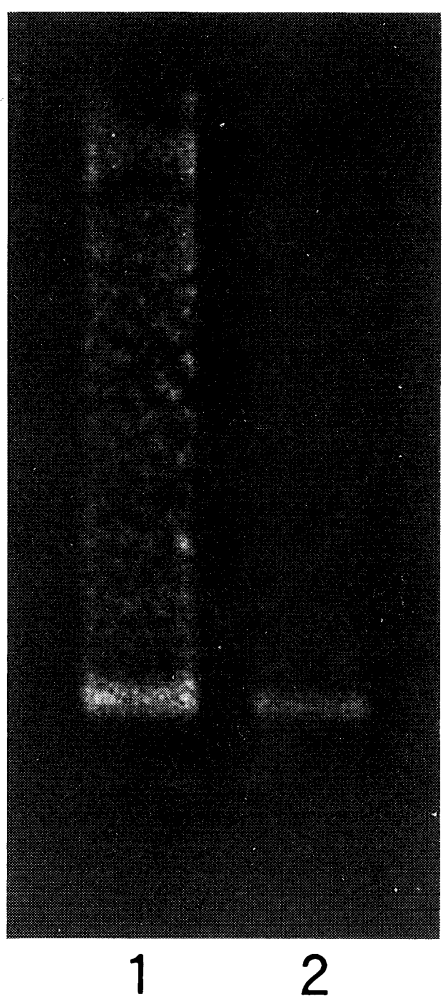

Fig. 7. Agarose gel electrophoresis of RT-PCR products for exon 2 to exon 5 . Each PCR product from a patient with the $\mathrm{C} \rightarrow \mathrm{T}$ change in intron $3(1)$ and a normal subject (2) revealed one band, which indicated no evidence of splicing abnormality. therefore no data are shown. Among the 5 remaining patients, one had impaired glucose tolerance and three had non-insulin dependent diabetes mellitus. There was no familial relationship between these patients.

\section{RFLP of ${ }^{1595} \mathbf{C} \rightarrow \mathbf{G}$ in exon 9}

Heterozygosity of ${ }^{1595} \mathrm{C} \rightarrow \mathrm{G}$ in exon 9 was identified in 5 hypertriglyceridemic patients. We did not investigate this mutation in the normolipidemic control subjects.

\section{RT-PCR}

RT-PCR products between exon 2 and exon 5 from one patient $(\mathrm{M}, 60 \mathrm{y})$ with a $\mathrm{C} \rightarrow \mathrm{T}$ transition in intron 3 and a normal control showed one band (Fig. 7) indicating no splicing abnormality between exon 2 and exon 5 .

\section{Discussion}

Various LPL gene defects have been reported and heterozygotes in family members of homozygotes have been found to show various types of hyperlipoproteinemia: type llb, IV and V. The activity or mass of LPL in post-heparin plasma among heterozygotes with LPL defects was different in each mutation and between each family member $(10,11)$. Takagi et al. identified some variants of the LPL gene by examining patients with low LPL mass (21). The activity or mass of some heterozygotes may be within normal limits. Therefore, we first examined the LPL gene by SSCP without measuring LPL activity or protein level, and then examined LPL mass of patients with abnormal LPL gene. No heterozygotes with LPL genetic defect were found among hypertriglyceridemic patients except for ${ }^{1595} \mathrm{C} \rightarrow \mathrm{G}$ in exon 9 which creates a premature termination codon $\left({ }^{447}\right.$ Serine $\rightarrow$ stop) but this was probably unrelated to hyperlipoproteinemia. We found a case of a homozygous novel nonsense mutation in exon 1 and also patients heterozygous for a novel polymorphism in intron 3.

The mutation in exon 1 was ${ }^{216} \mathrm{G} \rightarrow \mathrm{A}$ resulting in the substitution of a stop codon for tryptophan in the signal peptide of LPL. The proband was homozygous for this mutation and her LPL protein was completely defective. Although her children were heterozygous for this mutation, they presented with neither hypertriglyceridemia nor hyper- 
chylomicronemia and their LPL protein levels in post-heparin plasma were almost normal. It has been suggested that heterozygosity for LPL gene defects represents a precondition for hypertriglyceridemia (10). Several factors promoting clinical manifestation of the LPL gene defect are aging, obesity, hyperinsulinemia, and insulin resistance $(11,22)$. The heterozygous individuals in this study with the nonsense mutation, however, did not present with any of these modulators except aging, which would tend to maintain normolipidemia. The LPL gene with a stop codon in the signal peptide never produces mature LPL protein. Nevertheless, LPL protein levels in our heterozygotes were almost within normal limits. This may have been due to up-regulation of the other normal LPL allele.

This nonsense mutation was not found among other 105 hypertriglyceridemic patients or 105 normolipidemic subjects. It has been reported that in French Canadians, $15-20 \%$ of type IV and V hyperlipoproteinemic cases are associated with one of four kinds of LPL genetic defects (23). Such prevalence is high compared to our results. Our cases did not completely exclude secondary hypertriglyceridemia, and the SSCP method did not always detect all single base differences in DNA fragments. Therefore, our results did not reveal exactly the frequency of LPL gene mutations in primary hypertriglyceridemic patients. However, heterozygosity for the LPL defect appears to be infrequent among hypertriglyceridemic patients in Japan.

In this study, a $\mathrm{C} \rightarrow \mathrm{T}$ transition at 6 bp upstream from the splice acceptor site in intron 3 was found in six patients with hypertriglyceridemia, while this mutation was never found in normolipidemic healthy control subjects. There was a statistically significant difference between the frequencies of this mutation in hypertriglyceridemic and normolipidemic groups. ApoCll levels of three patients with the mutation were elevated, so their hypertriglyceridemia was not caused by ApoCll deficiency. Therefore, this change in the gene may be related to the mechanism of hypertriglyceridemia. There were no changes in each exon or in the region $690 \mathrm{bp}$ $5^{\prime}$ upstream from the ATG initiation codon, and no splicing abnormalities were found between exon 2 and exon 5 , so we cannot explain the relationship between the mutation and hypertriglyceridemia. It is assumed there may be an abnormal sequence in the promoter area beyond the upstream 5' flanking region, or this change in intron 3 may be linked to another gene which is involved in hypertriglyceridemia.

All of the patients with the $\mathrm{C} \rightarrow \mathrm{T}$ transition in intron 3 were male and 4 of the 5 patients who underwent laboratory examination had glucose intolerance. These results suggest that the $\mathrm{C} \rightarrow \mathrm{T}$ change may develop a hypertriglyceridemia with androgen or glucose intolerance. This polymorphism should be studied further in a large population and other promoter areas should be investigated to clarify their relationships to hypertriglyceridemia.

\section{Reference}

(1) Nilsson-Ehle P, Garfinkel AS, and Schotz MC: Lipolytic enzymes and plasma lipoprotein metabolism. Annu Rev Biochem, 49: 667-693, 1980

(2) Smith LC and Pownall HJ : Lipoprotein lipase. In : Lipase. eds by Borgstrom B and Brockman HL, pp 263-305, Elsevier, Amsterdam, 1984

(3) Jackson RL: Lipoprotein lipase and hepatic lipase. In: The Enzymes. ed by Boyer PD, 16: pp 141-181, Academic Press, New York, 1983

(4) Kinnunen PKJ: Hepatic endothelial lipase: isolation, some characteristics, and physiological role. In: Lipase. eds by Borgstrom B and Brockman HL, pp 307-328, Elsevier, Amsterdam, 1984

(5) Sparkes RS, Zollman S, Klisak I, Kirchgessner TG, Komaromy MC, Mohandas T, Schotz MC, and Lusis AJ: Human genes involved in lipolysis of plasma lipoproteins : mapping of loci for lipoprotein lipase to 8 p22 and hepatic lipase to 15q21. Genomics, 1: 138-144, 1987

(6) Kirchgessner TG, Svenson KL, Lusis AJ, and Schotz MC : The sequence of CDNA encoding lipoprotein lipase. J Biol Chem, 262 : 8463-8466, 1987

(7) Deeb SS and Peng RL: Structure of the human lipoprotein lipase gene. Biochemistry, 28: 4131-4135, 1989

(8) Wion KL, Kirchgessner TG, Lusis AJ, Schotz MC, and Lawn $\mathrm{RM}$ : Human lipoprotein lipase complementary DNA sequence. Science, 235 : 1638-1641, 1987

(9) Brunzell JD: Familial lipoprotein lipase deficiency and other causes of the chylomicronemia syndrome. In: The Metabolic Basis of Inherited Disease. ed by Scriver CR, Beaudet AL, Aly WS, and Valle D, pp 1165-1180, McGrawHill, New York, 1989

(10) Babirak SP, Iverius PH, Fujimoto WY, and Brunzell JD: Detection and characterization of the heterozygote state for lipoprotein lipase deficiency. Arteriosclerosis, 9: 326334, 1989

(11) Wilson DE, Emi M, Iverius $\mathrm{PH}$, Hata A, Wu LL, Hillas $\mathrm{E}$ Williams RR, and Lalouel JM: Phenotypic expression of heterozygous lipoprotein lipase deficiency in the extended pedigree of a proband homozygous for a missense mutation. J Clin Invest, 86: 735-750, 1990

(12) Gotoda T, Yamada N, Kawamura M, Kozaki K, Mori N, Ishibashi S, Shimano H, Takaku F, Yazaki Y, Furuichi $Y$, and Murase $T$ : Heterogeneous mutations in the human lipoprotein lipase gene in patients with familial lipoprotein lipase deficiency. J Clin Invest, 88: 1856-1864, 1991

(13) Lalouel JM, Wilson DE, Emi M, and Iverius PH : Lipoprotein lipase and hepatic triglyceride lipase: molecular a genetic aspects. Curr Opin Lipidol, 3: 86-95, 1992

(14) Orita M, Suzuki Y, Sekiya T, and Hayashi K: Rapid and sensitive detection of point mutations and DNA polymorphisms using the polymerase chain reaction. Genomics, 5: 874-879, 1989

(15) Yap EPH and McGee JOD : Nonisotopic SSCP detection in PCR products by ethidium bromide staining. Trends Genet, 8: 2, 1992

(16) Monsalve MV, Henderson H, Roederer G, Julien P, Deeb S, Kastelein JJP, Peritz L, Devlin R, Bruin T, Murthy MRV, Cagne C, Davignon J, Lupien PJ, Brunzell JD, and Hayden MR: A missense mutation at codon 188 of the human lipoprotein lipase gene is afrequent case of lipoprotein lipase deficiency in persons of different ancestries. J Clin 
Invest, 86: 728-734, 1990

(17) Stocks J, Thorn jA, and Galton DJ: Lipoprotein lipase genotypes for a common premature termination codon mutation detected by PCR-mediated site-directed mutagenesis and restriction digestion. J Lipid Res, 33: 853-857, 1992

(18) Ikeda Y, Takagi A, Ohkaru Y, Nogi K, Iwanaga T, Kurooka $S$, and Yamamoto $A$ : A sandwich-enzyme immunoassay for the quantification of lipoprotein lipase and hepatic triglyceride lipase in human pos-theparin plasma using monoclonal antibodies to the corresponding enzymes. $\mathrm{J}$ Lipid Res, 31: 1911-1924, 1990

(19) Oka K, Tkalcevic GT, Nakano T, Tucker H, Isimura-Oka K, and Brown WV : Structure and polymorphic map of human lipoprotein lipase gene. Biochim Biophys Acta, 1049 : 2126, 1990

(20) Enerback S, Ohlsson BG, Samuelsson L, and Bjursell G: Characterization of the human lipoprotein lipase (LPL) promoter: evidence of two cis-regulatory regions, LP- alpha and LP-beta, of importance for the differentiationlinked induction of the LPL gene during adipogenesis. Mol Cell Biol, 12: 4622-4633, 1992

(21) Takagi A, Ikeda Y, Mori A, Tsutsumi Z, Oida K, Nakai T, and Yamamoto A: A newly identified heterozygous lipoprotein lipase gene mutation $\left(\mathrm{Cys}^{239} \rightarrow\right.$ stop $/ \mathrm{TGC}^{972} \rightarrow \mathrm{TGA}$; LPLobama) in a patient with primary type IV hyperlipoproteinenia. J Lipid Res, 35 : 2008-2018, 1994

(22) Tenkanen $\mathrm{H}$, Taskinen $\mathrm{M}-\mathrm{R}$, Ankikainen $\mathrm{M}$, Ulmanen I, Kontula K, and Ehnholm C: A novel animo acid substitution $\left(\mathrm{His}^{183} \rightarrow \mathrm{GIn}\right)$ in exon 5 of the lipoprotein lipase gene results in loss of catalytic activity: phenotypic expression of the mutant gene in a heterozygous state. J Lipid Res, 35 : 220-228, 1994

(23) Minnich A, Kessling A, Roy M, Giry C, DeLangavant G, Lavigne J, Cacan SL, and Davignon J: Prevalance of alleles encoding defective lipoprotein lipase in hypertriglyceridemic patients of French Canadian descent. J Lipid Res, 36 : 117-124, 1995 